\title{
LABORATORY STUDIES ON THE EGYPTIAN PRAYING MANTIS Miomantis paykullii STAL, (MANTODEA: MANTIDAE)
}

Ata, T. E.

Dep. of Plant Protection. Fac. of Agric. Al-Azhar University. Cairo. Egypt.

\begin{abstract}
Certain biological aspects of the Egyptian praying mantis Miomantis paykullii (Stal, 1871) were studied in the laboratory. Results indicated that ootheca contained an average of 52.4 nymphs, with a mean length of $15.0 \mathrm{~mm}$. The total duration period of nymphal stage required $64.1 \pm 10.54$ and $54.8 \pm 6.54$ days for female and male respectively. The generation period was 99 days at daily mean of temperature $25.9 \mathrm{C}-$ and relative humidity percentage $45.0 \%$. Six nymphal instars were recorded for male whereas, seven instars were found for female. The fecundity of $M$. paykullii through the oviposition period was $336.2 \pm 56.78$ nymph per female.
\end{abstract}

\section{INTRODUCTION}

Miomantis paykullii (Stal, 1871). is a species of praying mantis belonging to genus Miomantis, family Mantidae, order Mantodea. Genus Miomantis has two synonym Calidomantis (Rehn 1901) and Oreomantis (Uvarov 1935), while species paykullii has four synonym savignyi (Saussure 1872), pharaonica (Saussure 1898), senegalensis (Schulthess-Rechberg 1899) and pharaonis (Kirby 1904). This species was found in different African countries, including Egypt, Ivory Coast, Ghana, Uganda, Senegal and Togo. Mantodea is a small insect order in number of species, it represented by 2452 species in 446 genera and 14 families distributed all over the world (Otte \& Spearman, 2005). Mantids of Egypt form one of unique and sophisticated mantis fauna on the planet, with 59 species in 21 genera and four families (Sawaby Rabab et al. 2010). All mantids are predators feeding mainly on other insects and arthropods (Preston, 1990; Ehrman, 1992). Mantids are diurnal insects live mainly on tropical and sub-tropical regions with only few species occur on cold area (Ehrman, 2001). In Egypt nymphs of M. paykullii appear during the early spring season and prefer green grasses and small plants (Sawaby Rabab et al. 2010)

These studies were initiated to fill in obvious gaps in the reproductive and developmental biology of this insect, as previous workers had published few data on the immature stages, number of nymphs per female, nymphal instars, immature mortality, generation period, life cycle and adult longevity.

\section{MATERIALS AND METHODS}

\section{Sources of insect:}

Adults (females and males) of the Egyptian praying mantis Miomantis paykullii (Stal, 1871) (Mantodea: Mantidae) were collected from the Horticulture Department farm, Faculty of Agriculture, Al-Azhar University at Nassr-City Cairo in March 2012. They were kept in glass cages $(70 \mathrm{~cm} x$ 
Ata, T. E.

$40 \mathrm{~cm} \times 40 \mathrm{~cm}$ ). Circle doors were cut into one glass side of each cage and covered with gauze to introduce prey into the cages. Adults of mantis were maintained in these cages, held at $23.9^{\circ} \mathrm{C}$ and $41.8 \%$ R.H. They were fed on moths of cotton leafworm (spodoptera littoralis) daily during eggs laying period.

\section{Insect rearing:}

To rear the various stages of $M$. paykullii and to carry out further biological studies, under laboratory conditions, Plastic jars $17 \mathrm{~cm}$ in length and $8 \mathrm{~cm}$ in diameter were used. Oothecae laid in the laboratory were measured with calipers accurate to $0.05 \mathrm{~mm}$ (Suckling, 1984). The number of newly hatched nymphs per each ootheca were counted then transferred to a rearing jar individually. Nymphs were fed daily with a mixture of different collected insects; aphids, jassids, cotton leafworm larvae, and moths while, adults were fed on cotton leaf worm moths. The biological data of different stages or instars of the insect were observed and recorded. Newly hatched nymphs of $M$. paykullii were replicated and daily observed. The moulting, the immature stages duration, adult stage, the pre-ovipositon, ovipositon, postovipostion periods and generation periods were recorded under the laboratory conditions. Captive mantids need additional water. Gently place a small wet sponge inside the container three times per week. The mantids will gather the water off the sponge.

\section{RESULTS AND DISCUSSION}

The obtained results presented in Table (1) showed that male and female of the Egyptian praying mantis $M$. paykullii are not equal in numbers of moulting and nymphal duration. The insect has six nymphal instars for male and seven for female, the last acdysis is followed by the adult stage.

Incubation period and duration of nymphal instars:

Incubation period of eggs laid by $M$. paykullii females previously fed on live insects and incubated at $23.9 \mathrm{C}^{\circ} \pm 3.7 \mathrm{C}^{\circ}$ and R.H. $41.8 \% \pm 12.1 \%$ required $20.1 \pm 1.98$ days in average. Egg-laying starts in February and continues while the females survive, which may be until April - May. The juveniles will spend five to six months in the egg case until hatching in springsummer. (Ramsay, 1990).

From the obtained data presented in Table (1), the $1^{\text {st }}$ nymphal instar lasted $10.0 \pm 2.62$ and $9.8 \pm 2.17$ days for female and male respectively at $24.1 C^{\circ} \pm 2.4 C^{\circ}$ and R.H. $41.4 \% \pm 12.0 \%$. The same observation was observed in the $2^{\text {nd }}$ instar; female required a longer time as $11.0 \pm 3.92$ days while male needs only $9.5 \pm 1.52$ days to complete the mentioned instar at $25.9 \mathrm{C}^{\circ} \pm 2.2 \mathrm{C}^{\circ} \mathrm{e}$ and R.H. $42.7 \% \pm 10.1 \%$. The short time was recorded in the $3^{\text {rd }}$ nymphal instar, as $6.7 \pm 1.86$ and $7.0 \pm 1.58$ days for female and male respectively at $26.2 \mathrm{C}^{\circ} \pm 2.2 \mathrm{C}^{\circ}$ and R.H. $42.0 \% \pm 10.0 \%$. Also each of the $4^{\text {th }}$ and $5^{\text {th }}$ instars required the same periods as $7.0 \pm 1.26$ and $7.5 \pm 0.89$ days for female and male respectively at $26.8 \mathrm{C}^{\circ} \pm 2.1 \mathrm{C}^{\circ}$ and R.H. $44.7 \% \pm 9.5 \%$, during the $4^{\text {th }}$ instar, also $6.2 \pm .0 .45$ and $7.5 \pm 1.64$ days for female and male at $27.5 \mathrm{C}^{\circ} \pm 1.4 \mathrm{C}^{\circ}$ and R.H. $46.0 \% \pm 9.0 \%$, during the $5^{\text {th }}$ instar. 
However, the $6^{\text {th }}$ instar as a penultimate nymphal instar for female but it was the last instar for male; it required $9.2 \pm 3.96$ days for female at $27.8 \mathrm{C}^{\circ} \pm 1.3 \mathrm{C}^{\circ}$ and R.H. $46.6 \% \pm 7.4 \%$. The longest instar was recorded in the last nymphal instar for both female $\left(7^{\text {th }}\right.$ instar) and male ( $6^{\text {th }}$ instar). The last nymphal instar for female was $14.0 \pm 6.56$ days at $29.2 C^{\circ} \pm 1.3 C^{\circ}$ and R.H. $50.7 \% \pm 5.4 \%$, while it was $13.5 \pm 2.07$ days in the last nymphal instar of male $\left(6^{\text {th }}\right.$ instar) at $27.8 \mathrm{C}^{\circ} \pm 1.3 \mathrm{C}^{\circ}=$ and R.H. $46.6 \% \pm 7.4 \%$.

Table (1): Certain biological aspects of immature stages of the Egyptian praying mantis Miomantis paykullii under laboratory conditions.

\begin{tabular}{|c|c|c|c|c|c|}
\hline \multirow{2}{*}{ Stages } & \multicolumn{2}{|c|}{ Duration (in days) } & \multirow{2}{*}{ Mortality (\%) } & \multirow{2}{*}{ Temp ${ }^{\circ} \mathrm{C}$} & \multirow{2}{*}{ R.H.\% } \\
\hline & Female & Male & & & \\
\hline Incubation period & \multicolumn{2}{|c|}{$20.1 \pm 1.98$} & & $23.9 \pm 3.7$ & $41.8 \pm 12.1$ \\
\hline 1st. nymphal Ins. & $10.0 \pm 2.62$ & $9.8 \pm 2.17$ & 9.8 & $24.1 \pm 2.4$ & $41.4 \pm 12.0$ \\
\hline 2nd. nymphal Ins. & $11.0 \pm 3.92$ & $9.5 \pm 1.52$ & 10.4 & $25.9 \pm 2.2$ & $42.7 \pm 10.1$ \\
\hline 3rd. nymphal Ins. & $6.7 \pm 1.86$ & $7.0 \pm 1.58$ & 0 & $26.2 \pm 2.2$ & $42.0 \pm 10.0$ \\
\hline 4th. nymphal Ins. & $7.0 \pm 1.26$ & $7.5 \pm 0.89$ & 0 & $26.8 \pm 2.1$ & $44.7 \pm 9.5$ \\
\hline 5th. nymphal Ins. & $6.2 \pm .0 .45$ & $7.5 \pm 1.64$ & 0 & $27.5 \pm 1.4$ & $46.0 \pm 9.0$ \\
\hline 6th. nymphal Ins. & $9.2 \pm 3.96$ & $13.5 \pm 2.07$ & 0 & $27.8 \pm 1.3$ & $46.6 \pm 7.4$ \\
\hline 7th. nymphal Ins. & $14.0 \pm 6.56$ & - & 0 & $29.2 \pm 1.3$ & $50.7 \pm 5.4$ \\
\hline Nymphal stage & $64.1 \pm 10.54$ & $54.8 \pm 6.54$ & 20.2 & $26.6 \pm 2.9$ & $44.8 \pm 10.2$ \\
\hline
\end{tabular}

The total duration of nymphal stage of $M$. paykullii required $64.1 \pm 10.54$ and $54.8 \pm 6.54$ days for female and male respectively to complete their development at $26.6 \pm 2.9 \mathrm{C}-$ and R.H. $44.8 \% \pm 10.2 \%$. There are usually 6-8 moults during the immature stages of Miomantis savignyi and it may pass the winter months in any stage, young, adult, or oothecae; the postembryonic stage varies from 2 to 8 months, and the adults vary to the same extent Adair (1924). Nymphs of Orthodera novaezealandiae go through six instars, taking three to six months until becoming adults (Walsby, 1996). Six nymphal instars occurred on Orthodera ministralis, (Suckling 1984). Although this may be variable depending on the availability of food to the developing nymphs, as in Paratenodera augustipennis (Matsura, et al. 1975).

\section{Nymphal mortality:}

During the development of nymphal stage it may suffer mortality which differs among instars. As shown in Table (1) both $1^{\text {st }}$ and $2^{\text {nd }}$ instars suffered the highest rates of mortality. The mortality percentage was $9.8 \%$ for $1^{\text {st }}$ nymphal instar at $24.1 \mathrm{C}^{\circ} \pm 2.4 \mathrm{C}^{\circ}$ and R.H. $41.4 \% \pm 12.0 \%$. While it was $10.4 \%$ for $2^{\text {nd }}$ nymphal instar at $25.9 C^{\circ} \pm 2.2 C^{\circ}$ and R.H. $42.7 \% \pm 10.1 \%$. Obviously no mortality were recorded or completely absent among nymphs during the other following instars of this insect. The total of nymphal mortality averaged $20.2 \%$ at $26.6 \mathrm{C}- \pm 2.9$ Co and R.H. $44.8 \% \pm 10.2 \%$. Mortality occurred among individuals of the various nymphal instars may be due to failure in acdysis, natural mortality. A large number of young failed the first moult, and nymphs lost about $50 \%$ of the young at each moult of Miomantis savigny (Adair, 1924). 
Ata, T. E.

Sexual reproductive periods and egg laying:

From the data presented in Table (2) the total life cycle of $M$. paykullii lasted $84.2 \pm 11.0$ days at $25.6 \mathrm{C}^{\circ} \pm 3.8 \mathrm{C}^{\circ}$ and R.H. $44.1 \% \pm 11.1 \%$. The preoviposition period extended to $14.8 \pm 6.18$ days at $28.7 \mathrm{C}^{\circ} \pm 1.4 \mathrm{C}^{\circ}$ and R.H. $49.5 \% \pm 7.7 \%$. Adair (1924) recorded that the paired females of Miomantis savigny laid oothecae 8-11 days after the last moult while unmated females laid 14-28 days after the last moult. Suckling, (1984) observed that the oviposition of Orthodera ministralis, began immediately in some females, and in a few cases continued to do so until late June, far later than normal for Palmerston North (April-May).

Table (2): Certain biological aspects of the Egyptian praying mantis Miomantis paykullii adult under laboratory conditions.

\begin{tabular}{|c|c|c|c|}
\hline Biol. aspects & Duration (in days) & Temp ${ }^{\circ} \mathbf{C}$ & R.H.\% \\
\hline Total life cycle (days) & $84.2 \pm 11.0$ & $25.6 \pm 3.8$ & $44.1 \pm 11.1$ \\
\hline Pre-oviposition period & $14.8 \pm 6.18$ & $28.7 \pm 1.4$ & $49.5 \pm 7.7$ \\
\hline Oviposition. Period & $36.2 \pm 4.71$ & $29.1 \pm 1.3$ & $51.1 \pm 6.5$ \\
\hline Post-oviposition period & $10.0 \pm 4.20$ & $30.1 \pm 1.1$ & $53.7 \pm 7.2$ \\
\hline Adult longevity & $61.0 \pm 10.20$ & $29.5 \pm 1.14$ & $52.0 \pm 7.5$ \\
\hline Generation period & $99.0 \pm 5.69$ & $25.9 \pm 3.8$ & $45.0 \pm 11.1$ \\
\hline Lifespan & $145.2 \pm 21.2$ & $27.4 \pm 3.7$ & $48.1 \pm 10.7$ \\
\hline Fecundity & $336.2 \pm 56.78$ & & \\
\hline
\end{tabular}

Oviposition period lasted $36.2 \pm 4.71$ days at $29.1 C^{\circ} \pm 1.3 C^{\circ}$ and R.H. $51.1 \% \pm 6.5 \%$, (Table 2). Through this period female deposited $6.42 \pm 1.1$ ootheca/female in average. About $52.4 \pm 9.08$ nymphs were emerged from ootheca, with mean length of $15.0 \mathrm{~mm}$, considerably smaller than reported by Adair (1924) in Egypt, the size of oothecae laid by unfertilised females of $M$. savigny may be longer than $25 \mathrm{~mm}$ in $6 \%$ of cases, oothecae from paired females never exceed $25 \mathrm{~mm}$. Also it is considerably smaller than reported for other mantis species; Orthodera ministralis it was $11.3 \mathrm{~mm}$, (Suckling, 1984) while Sharell (1971) stated that it was $20 \mathrm{~mm}$.

The fecundity of $M$. paykullii through the oviposition period was $336.2 \pm 56.78$ nymphs/female. Number of eggs in each ootheca is very variable, Orthodera ministralir (Fabricius). being as high as 70 and as low as 5, with 20-40 most common 34 average(Suckling, 1984). Oothecae in other mantids contain 10-400 eggs (Key 1970).

Post-oviposition period lasted $10.0 \pm 4.20$ day at $30.1 \mathrm{C}^{\circ} \pm 1.1 \mathrm{C}^{\circ}$ and R.H. $53.7 \% \pm 7.2 \%$. Adults of the M. paykullii survived about two months at $29.5 \mathrm{C}^{\circ} \pm 1.14 \mathrm{C}^{\circ}$ and R.H. $52.0 \% \pm 7.5 \%$.

\section{ACKNOWLEDGMENTS}

I would like to thank Professor Ibrahim Labib Ibrahim and Professor Abd Rabo Eid Husain, Dep. of Plant Protection. Fac. of Agric, Al-Azhar University, Cairo, Egypt for their assistance during this work. And deep thanks to Professor M. K. El-Akkad, insect survey and identification section, Plant Protection Research Institute for identification of mantis species. 


\section{REFERENCES}

Adair, E.W. (1924): On parthenogenesis in Miomanris savigny Saussure. Bull. Soc. Enromol. Egypte, Cairo, 8: 104-148.

Ehrmann, R. (1992): Wirbeltiereals Nahrung von Gottesanbeterinnen (Mantodea) Entomol. Zeitschr., 102 (9): 153-162.

Ehrmann, R. (2001): Gottesanbeterinnen (Mantodea)-Eine Ubersicht: Teil 1: Stammesge-schichte, Systematik, Korperbau, Fortpflanzung. Reptilia, 6 (28): 26-32.

Key, K. H. L. (1970): Mantodea. pp. 294-301 In The Insects of Australia. Melbourne, C.S.I.R.O.

Kirby, (1904): Syn. Cat. Orth. 1:257

Matsuraj, T.; Inoue, H. and Osomi, Y. (1975): Ecological studies of a mantid Paratenodera augustipennzs De Sassure. I. Evaluation of the feeding conditions in natural habitats. Research on population ecoloa (Kyoto) 17: 64-76.

Otte, D. and Spearman, L. (2005): Mantid- species file. Catalog of the Mantids of the World. Insect Diversity Association Publication, 1:1- 489.

Preston-Mafham, K.G. (1990): Grasshoppers and Mantids of the world. Blandford Book, (119-120).

Ramsay, G. W. (1990): Mantodea (Insecta) with a review of aspects of functional morphology and biology. Fauna of New Zealand 19:1-96.

Rehn. (1901): Can. Ent. 33:271

Saussure. (1872): Mem. Soc. Phys. Hist. nat. Geneve 23:66

Saussure. (1898): Rev. suisse Zool. 5:183

Sawaby, Rabab F.; El-Hamouly, Hayam and Nasser, M. G. E. (2010): Pilot study of population density and biodiversity index of Mantodea fauna in El- Fayoum governorate- Egypt. Acad. J. biolog. Sci., 3 (2): $19-26$.

Schulthess-Rechberg. (1899): Bull. Soc. vaud. Sci. nat. 35:196

Sharell, R. (1971): insects and their story New Zealand. Auckland, Collins. 268p.

Stal. (1871): Ofvers. K. VetensAkad. Forh. Stockh. 28(3):399

Suckling, D. M. (1984): Laboratory studies on the praying mantis Orthodera ministralis (Mantodea: Mantidae). New Zealand Entomologist 8:96-101.

Uvarov. (1935): Annls Mag. nat. Hist. 10 16:207

Walsby, J. (1996): On a wing and a prayer. New Zealand Geographic 29:100116. 
Ata, T. E.

Miomantis paykullii STAL, دراسات معلية على فرس النبى المصرى

(Mantodea: Mantidae)

طارق السيد عطا

قسم وقاية النبات ـ كلية الزراعة بالقاهرة - جامعة الازهر

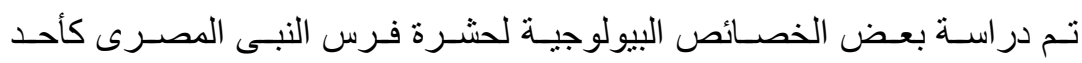

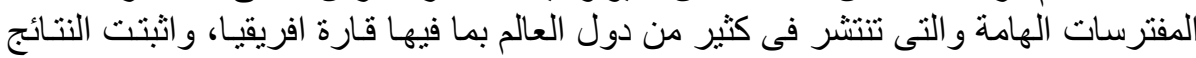

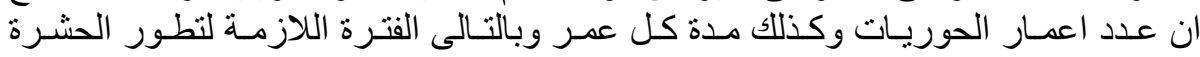

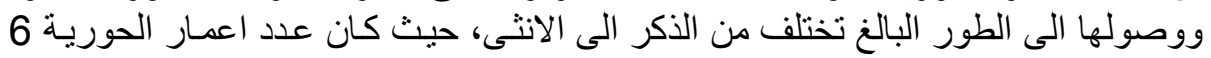

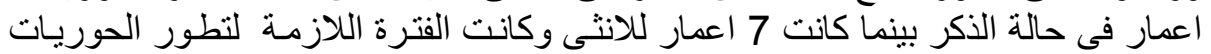

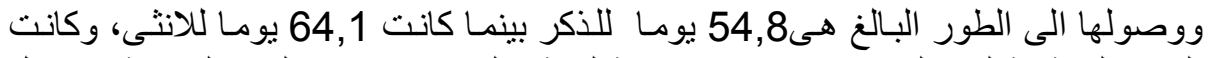

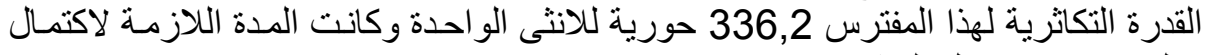

$$
\text { جيل واحد من اجيال الحشرة هي لفز } 99 \text { يو ما. }
$$

كلية الزراعة - جامعة المنصورة كلية الزراعة - جامعة الأزهر
قام بتحكيم البحث

أ.د / أبر / عبد البديع عبد الحميد غانم

أ.د / ابراهيم لبيب ابر البيم الهميد عيم 